\title{
Effects of mild drought on the morphology of sun and shade needles in 20-year-old Norway spruce trees
}

\author{
Roman Gebauer ${ }^{(1)}$, \\ Daniel Volařík ${ }^{(1)}$, \\ Josef Urban ${ }^{(1-2)}$, \\ Isabella Børja ${ }^{(3)}$, \\ Nina Elisabeth Nagy $^{(3)}$, \\ Toril Drabløs Eldhuset ${ }^{(3)}$, \\ Paal Krokene ${ }^{(3)}$
}

\begin{abstract}
Several studies have looked at how individual environmental factors influence needle morphology in conifer trees, but interacting effects between drought and canopy position have received little attention. In this study, we characterized morphological responses to experimentally induced drought stress in sun exposed and shaded current-year Norway spruce needles. In the drought plot trees were suffering mild drought stress, with an average soil water potential at $50 \mathrm{~cm}$ depth of $-0.4 \mathrm{MPa}$. In general, morphological needle traits had greater values in sun needles in the upper canopy than in shaded needles in the lower canopy. Needle morphology 15 months after the onset of drought was determined by canopy position, as only sun needle morphology was af fected by drought. Thus, canopy position was a stronger morphogenic factor determining needle structure than was water availability. The largest influence of mild drought was observed for needle length, projected needle area and total needle area, which all were reduced by $\sim 27 \%$ relative to control trees. Needle thickness and needle width showed contrasting sensitivity to drought, as drought only affected needle thickness (10\% reduction). Needle dry mass, leaf mass per area and needle density were not affected 15 months after the onset of mild drought. Our results highlight the importance of considering canopy position as well as water availability when comparing needle structure or function between conifer species. More knowledge about how different canopy parts of Norway spruce adapt to drought is important to understand forest productivity under changing environmental conditions.
\end{abstract}

Keywords: Canopy Position, Drought, Crown Light Gradient, Needle Structure, Picea abies, Transpiration

\section{Introduction \\ Trees are constantly adapting to shifting environmental conditions such as light and water availability by modifying their physi- ology and morphology. Norway spruce (Picea abies [L.] Karst.), which is the most important commercial tree species in many European countries, is relatively sensitive}

(1) Department of Forest Botany, Dendrol ogy and Geobiocoenology, Mendel University in Brno, Zemedelská 3, 61300 Brno (Czech Republic); (2) Siberian Federal University, Krasnoyarsk (Russia); (3) Norwegian Institute of Bioeconomy Research, PO Box 115, N-1431 Ås (Norway)

\section{@ Roman Gebauer (gebo@email.cz)}

Received: Apr 10, 2018 - Accepted: Oct 30, 2018

Citation: Gebauer R, Volařík D, Urban J, Børja I, Nagy NE, Eldhuset TD, Krokene P (2019). Effects of mild drought on the morphology of sun and shade needles in 20year-old Norway spruce trees. iForest 12: 27 34. - doi: 10.3832/ifor2809-011 [online 201901-10]

Communicated by: Tamir Klein to drought (Wallin et al. 2002). Indeed, drought is suggested to be the driving factor behind the ongoing dieback of Norway spruce in many places in Europe (Hentschel et al. 2014), highlighting the need for more knowledge about how Norway spruce responds to environmental changes.

A tree's ability to survive drought depends on different anatomical, morphological, and physiological factors. Several reports of Norway spruce responses to drought have focused on transpiration (Strelcová et al. 2013), stomatal function (Kurjak et al. 2012), tree growth (Sohn et al. 2012), monoterpenes (Turtola et al. 2003), xylem embolism (Chmura et al. 2016), fine roots (Konôpka \& Lukac 2013) or cell organelles (Zellnig et al. 2004). However, very few studies have focused on the structural response of Norway spruce needles to drought, even though needles are the key organ for photosynthesis and transpiration. One of the few existing studies on Norway spruce needles found that drought reduced needle tracheid dimensions, needle cross-sectional area, and needle xylem area (Gebauer et al. 2015). In another study, drought was found to increase the area of the needle vascular cylinder (Kivimäenpää et al. 2003), but Gebauer et al. (2015) observed negligible changes in this trait.
Light availability is another important factor modifying needle development, and even within a single tree the needles have different structure and function according to light gradients within the canopy (Woodruff et al. 2004). Photosynthetically active radiation (PAR) displays steep vertical gradients within Norway spruce crowns (Kučera et al. 2002), and this favors the differentiation of typical sun and shade adapted needles (Spunda et al. 1998). Relative to shade adapted needles, sun needles are generally shorter (Kubínová et al. 2018) and have higher density (Niinemets \& Kull 1995), more tracheids (Gebauer et al. 2015), larger xylem area (Gebauer et al. 2015), higher leaf mass per area (Niinemets \& Kull 1995), greater surface area of mesophyll (Lhotáková et al. 2012) and rounder crosssections (Kubínová et al. 2018). Under natural conditions drought episodes often increase light availability inside the canopy, because drought-stressed trees often shed some foliage or whole branches die off.

A few studies have described the interacting effects of drought and light intensity on seedling growth (Holmgren 2000, Aranda et al. 2005). However, to our knowledge, studies of interacting effects of drought and light intensity (i.e., canopy position) are limited to our recent study on needle xylem/phloem area, needle cross- 
sectional area and tracheid dimensions in Norway spruce (Gebauer et al. 2015). Increased knowledge about needle development in response to interacting effects of drought and canopy position is crucial to understand forest productivity and for ecosystem modelling (Niinemets \& Kull 1995).

In this study we aim to characterize morphological responses to drought stress of sun-exposed and shaded current-year needles in young $(\sim 20$ years old) Norway spruce trees. We test the following three hypotheses: $\left(\mathrm{H}_{1}\right)$ canopy position will strongly influence needle morphology; $\left(\mathrm{H}_{2}\right)$ drought will alter the morphology of sun and shade needles as a result of water shortage during cell division and development; and $\left(\mathrm{H}_{3}\right)$ the interaction between drought and canopy position will result in stronger morphological reductions in sun adapted needles as compared to shade adapted needles.

\section{Material and methods}

\section{Study site and experimental design}

This study follows up previous studies in the same experimental stand (see Gebauer et al. 2011, 2015) and we sampled needles from the same trees used in these studies. Further details about the study site and experimental design can be found in Gebauer et al. (2011). Briefly, we used $\sim 20$-year-old Norway spruce trees that had been planted in a $1 \times 1 \mathrm{~m}$ grid on former agricultural soil in 1990 in Ås, south-eastern Norway. Soil type was classified as albeluvisol. The mean annual precipitation is $785 \mathrm{~mm}$ and mean annual temperature $5.3^{\circ} \mathrm{C}$, according to data from the meteorological station in Ås, $3.9 \mathrm{~km}$ from the study site (Hansen \& Grimenes 2003). Mean stand height, stand density and basal area were $8.5 \pm 1.4 \mathrm{~m}$, 10,000 trees ha ${ }^{-1}$, and about $50 \mathrm{~m}^{2} \mathrm{ha}^{-1}$, respectively. Fine roots were abundant down to a soil depth of $60 \mathrm{~cm}$ in October 2010 (Børja et al. 2017). Two study plots, about $150 \mathrm{~m}^{2}$ each and situated $\sim 15 \mathrm{~m}$ apart, were established within the stand. In each plot, we selected three individual trees, each from a different full-sib family (both plots had the same full-sib families - see Gebauer et al. 2011 for data on stem and crown dimensions of each tree). Trees standing along the edges of the plots were not selected. One plot received natural rainfall and served as the control plot. On the other plot (drought plot) the three selected trees were standing in one row and the two rows of trees flanking the experimental trees were removed in August 2008. In May 2009, a plastic roof covering the entire drought plot was set up under the tree crowns. Thus, light quantities and qualities within the tree crowns were not influenced by the plastic roof. The roof was sealed onto the stems using silicone putty to prevent precipitation run-off along the stem from reaching the soil. A $30 \mathrm{~cm}$ deep trench was dug around the plot to intercept the precipitation and soil water. The trench was dug outside the flanking tree rows to avoid damaging the roots of the experimental trees. On 4 July 2009, trees flanking the control trees were removed to create similar tree density and light condition as in the drought plot.

Meteorology, soil water potential, light intensity and sap flow measurement

A climatic station was set up on an open field $100 \mathrm{~m}$ from the experimental plots to measure global radiation, air temperature and relative air humidity using EMS11 and EMS33 (EMS Brno, Czech Republic), as well as precipitation and wind speed (MetOne Instruments, Grants Pass, OR, USA). Soil water potential (SWP) was monitored in triplicate measurements on both plots at 10,30 and $50 \mathrm{~cm}$ soil depth using gypsum blocks (Delmhorst Inc., Towaco, NJ, USA). All these measurements were carried out from the beginning of the vegetation period until needles were sampled (i.e., from 17 May to 7 August 2010). The amount of PAR (photosynthetically active radiation) in the two stands was measured under cloudless conditions on 4 August 2010 at 12:00 and 17:00 and compared to the PAR at an open plot nearby. At each canopy height, 100 independent PAR measurements were taken within five minutes using an $\mathrm{EMS} 12^{\circledR}$ sensor (EMS Brno, Czech Republic). Sap flow was monitored from 17 May to the end of August 2010 in all six experimental trees, using $\mathrm{EMS} 51^{\oplus}$ sap flow meters (EMS Brno, Czech Republic) working under the trunk heat balance principle (Cermák et al. 1973). Sap flow was measured at $1.3 \mathrm{~m}$ height on the north-facing side of each tree. Tree sap flow was standardized as per unit crown projected area and expressed in millimeters (i.e., liters per $\mathrm{m}^{2}$ ). We considered sap flow to equal transpiration over the season. Shoot water potential was measured on excised sun exposed shoots from the upper 1-2 $\mathrm{m}$ of the crown of each tree on 4 August 2010 at 2:00 pm using a Scholander pressure chamber. See Gebauer et al. (2015) for a more detailed description of measurements of sap flow, PAR, and tree and soil characteristics.

\section{Plant material}

From each of the three experimental trees per treatment, five current-year shoots were collected near the top of the tree (sun needles: upper 1-2 $\mathrm{m}$ of the crown) and five current-year shoots were collected at the bottom of the crown (shade needles: 3.8-4.2 $\mathrm{m}$ above ground) on 7 August 2010, i.e., 15 months after roof installation. The mean length of the living crown in the six experimental trees was 5.7 $\mathrm{m}$. Shoots were sampled from the outer part of the southern side of the crown to minimize the effect of any microclimatic differences within the stand or canopy (Lhotáková et al. 2007). Samples were fixed in FAA solution ( $90 \mathrm{ml}$ of $70 \%$ ethanol, 5 $\mathrm{ml}$ of acetic acid, and $5 \mathrm{ml}$ of $40 \%$ formaldehyde).

\section{Needle analysis}

From each sampled shoot we selected seven needles for morphological character- 
ization. Needles were collected at regular intervals along the shoot axis to cover possible within-shoot heterogeneity in needle morphology. Altogether 35 needles from each tree canopy position were analyzed ( 7 needles $\times 5$ shoots). Needle cross-sections were taken near the needle base. All needle cross-sections were examined under a light microscope (Olympus $B \times 5^{\circledR}{ }^{\circledR}$, Olympus (zech Group), and photographed using a digital camera (Olympus E-330 ${ }^{\circledR}$, Olympus Czech Group) connected to a computer by the software QuickPhotomicro ${ }^{\circledR}$ ver. 2.3 (Promicra, Czech Republic). Needle thickness $\left(D_{1}\right)$ and needle width $\left(D_{2}\right)$ were determined from the sections using ImageJ ver. 1.45 analyzing software (The University of Texas Health Science Center, San Antonio, TX, USA - Fig. 1). Needle cross-sectional shape (i.e., needle flatness $F_{n}$ ) was calculated as the ratio $D_{1} / D_{2}$. A needle with a round or square cross-section will have $F_{n}$ close to 1 , and larger $F_{n}$ characterizes more flattened needles.

In this study, we also included four anatomical needle traits described in a previous paper (Gebauer et al. 2015) to determine their relationships with different measured and calculated morphological needle traits (summarized in Tab. 1). The four anatomical traits $\left(A_{\text {lum }}\right.$ : tracheid lumen area; $A_{n}$ : cross-sectional needle area; $A_{x}$ : xylem area; $\mathrm{N}_{\mathrm{t}}$ : number of tracheids - see Fig. 1) were measured from the same needles used in measuring $D_{1}$ and $D_{2}$. To evaluate $A_{\text {lum }}$ and $N_{t}$, tracheid lumina were manually coloured using Adobe Photoshop ${ }^{\circledR}$ ver. 9.0 (Adobe Systems, San Jose, CA, USA) before $A_{\text {lum }}, N_{t}$ and other anatomical needle traits were determined using ImageJ analysing software (see Gebauer et al. 2015 for more details). To determine leaf mass per area (LMA) and associated needle traits, 10 randomly selected sun needles and 10 shaded needles were taken from the same five sun and shade shoots sampled from each tree on 7 August 2010. The needles were first scanned to determine projected leaf area (PLA) and needle length $\left(L_{n}\right)$ and then dried at $85^{\circ} \mathrm{C}$ for 48 hours to determine needle dry matter (DM). PLA and $L_{n}$ were determined using the software ImageJ. LMA was calculated as the ratio DM/PLA. Needle density $\left(T D_{n}-\right.$ eqn. 1$)$ and total needle area (TLA - eqn. 2) were calculated according to Sellin (2000):

$$
\begin{aligned}
& T D_{n}=\frac{D M \cdot \sqrt{D_{1}^{2}+D_{2}^{2}}}{P L A \cdot D_{1}^{2}} \\
& T L A=\frac{4 r L_{n} \sqrt{D_{1}^{2}+D_{2}^{2}}+(1-r) \pi L_{n} \sqrt{D_{1}^{2}+D_{2}^{2}}}{2}
\end{aligned}
$$

where $r=0.75$ is the proportion of total needle length that is made up by the rectangular part of the needle projection (Sellin 2000).

\section{Statistical analysis}

We analyzed differences in monthly and seasonally accumulated sap flow between

Tab. 1 - Norway spruce needle traits, their abbreviations and units used in the study. (*): Traits in italics are anatomical traits taken from Gebauer et al. (2015).

\begin{tabular}{|lll|}
\hline Trait & Explanation & Units \\
\hline$A_{\text {lum }}$ & tracheid lumen area & $\mu \mathrm{m}^{2}$ \\
\hline$A_{n}$ & cross-sectional needle area (Fig. 1) & $\mathrm{mm}^{2}$ \\
\hline$A_{\mathrm{x}}$ & xylem area (Fig. 1) & $\mu \mathrm{m}^{2}$ \\
\hline$D_{1}$ & needle thickness (Fig. 1) & $\mathrm{mm}$ \\
\hline$D_{2}$ & needle width (Fig. 1) & $\mathrm{mm}$ \\
\hline DM & mean needle dry mass & $\mathrm{mg}$ \\
\hline$F_{n}$ & needle flatness (D $\left./ D_{2}\right)$ & - \\
\hline$L_{n}$ & needle length & $\mathrm{mm}$ \\
\hline LMA & leaf mass per area (DM/PLA) & $\mathrm{g} \mathrm{m}^{-2}$ \\
\hline$N_{\mathrm{t}}$ & number of tracheids in needle & - \\
\hline PLA & mean needle projected area & $\mathrm{mm}^{2}$ \\
\hline TD & needle tissue density (eqn. 1) & $\mathrm{g} \mathrm{cm}^{-3}$ \\
\hline TLA & total needle area (eqn. 2) & $\mathrm{mm}^{2}$ \\
\hline
\end{tabular}

control trees and trees subjected to drought using a two-sample two-tailed $t$ test at the 0.05 significance level. For analysis of needle morphological traits, we used linear mixed effect models (LME Zuur et al. 2009). LME were used because of our hierarchical sampling strategy, where needles were collected from different trees (three trees per treatment) and from five different shoots on each tree and canopy position. LME allowed to consider variation among and within trees and shoots by specifying individual shoots within trees as a random effect. Some needle traits (DM, $L_{n}, L M A, P L A, T D_{n}, T L A$ and TLA/PLA - Tab. 1) were determined not on an individual needle level, but as the average of 10 sun or shade needles per tree. For these traits, tree was specified as a random effect and the explanatory variables canopy position (sun/shade) and drought treatment (control/drought) were set as fixed effects. In the statistical analyses, a model for each needle trait was first fitted with each of the explanatory variables. In a subsequent model, both canopy position and drought were included, and then also the interaction canopy position $\times$ drought was added. To test for the significance of canopy position and drought and obtain appropriate p-values we adopted the approach described by Zuur et al. (2009). Briefly, we used likelihood ratio tests to compare each simpler model (incorporating either canopy position or drought) with the more complex model (incorporating canopy position, drought, and their interaction). To summarize our sampling design, we had 3 trees per treatment ( 6 trees in total), 2 canopy positions per tree (sun needles, shade needles), 5 shoots per canopy position, and 7 needles per shoot. Needle traits were determined either at the individual needle level or at the canopy position level (Tab. 2).

To evaluate the relationships between selected morphological $\left(D_{1}, D_{2}, D M, T D_{n}, L_{n}\right.$, LMA) and anatomical $\left(A_{\text {lum }}, A_{n}, A_{x}, N_{t}\right)$ needle traits we used a similar approach as described above for analysis of needle anatomical traits. We used LME and specified one trait as the variable to be explained and the other as the explanatory variable (fixed effect). We also included the synergistic (fixed) effect of canopy position, as this was found to be important in our previous analysis. Tree was used as a random effect for models with $\mathrm{DM}, \mathrm{TD}_{\mathrm{n}}$ and LMA. For models with other variables (analysed on shoot level), tree and shoot were used as random effects. For shoot-level traits we used the within-subject centering approach (Van Pol \& Wright 2009) to separate between- and within-shoot effects (only between-shoot effects are reported).

All statistical analyses were carried out in the $\mathrm{R}$ software environment ( $\mathrm{R}$ Core Team 2015) using the packages "Ime4" ver. 1.1-7 (Bates et al. 2014) for LME calculations and "ImerTest" ver. 2.0-25 (Kuznetsova et al. 2015) for calculation of $95 \%$ confidence intervals of population means for fixed effects.

\section{Results}

Meteorology, soil water potential, light intensity and sap flow

Total precipitation during the experimental period from 17 May to 7 August 2010 (the day of needle sampling) was $232 \mathrm{~mm}$, Penman-Monteith-based reference evapotranspiration $313 \mathrm{~mm}$, mean air temperature $14.8{ }^{\circ} \mathrm{C}$, and mean vapor pressure deficit $359 \mathrm{~Pa}$. Total precipitation in the year preceding the needle sampling (8 August 2009-7 August 2010) was $768 \mathrm{~mm}$ and mean air temperature was $4.9^{\circ} \mathrm{C}$. This was below the long-term average (by $17 \mathrm{~mm}$ and $0.4{ }^{\circ} \mathrm{C}$ ). The soil in the control plot was almost constantly wet, with only one short period of drought in late July. Mean SWP in the control plot varied from -1.1 to -0.02 MPa at different depths from early May to late August. In contrast, SWP in the upper soil layers of the drought plot was always below -1.1 MPa, the lower limit that could be measured by the gypsum blocks. However, average SWP at $50 \mathrm{~cm}$ soil depth in the drought plot was $-0.42 \pm 0.06 \mathrm{MPa}$, indicating that some water was available in deeper soil layers. 
Tab. 2 - Mean values and 95\% confidence intervals fitted by linear mixed effect models (LME) for morphological traits of sun and shade needles from Norway spruce trees subjected to drought stress and control trees receiving natural rainfall. For each needle trait the model with the lowest AIC* value is considered better. For an explanation of the different needle traits, see Tab. $1 .\left(^{*}\right)$ : Akaike Information Criterion; (**): effect of drought was significant only for sun needles.

\begin{tabular}{|c|c|c|c|c|c|c|c|}
\hline \multirow{2}{*}{$\begin{array}{l}\text { Needle } \\
\text { trait }\end{array}$} & \multicolumn{2}{|c|}{ Shade needles } & \multicolumn{2}{|c|}{ Sun needles } & \multirow{2}{*}{ Model } & \multirow{2}{*}{$\mathrm{AIC}^{*}$} & \multirow{2}{*}{ P-value } \\
\hline & Control & Drought & Control & Drought & & & \\
\hline \multirow[t]{3}{*}{ D1 } & 0.89 & 0.89 & 1.19 & 1.07 & canopy position & 4618 & $<0.001$ \\
\hline & $(0.80-0.99)$ & $(0.79-0.99)$ & $(1.10-1.28)$ & $(0.98-1.17)$ & drought & 5000 & 0.19 \\
\hline & - & - & - & - & drought $\times$ canopy position** & 4585 & $<0.001$ \\
\hline \multirow[t]{3}{*}{ D2 } & 0.55 & 0.55 & 0.98 & 0.94 & canopy position & 4614 & $<0.001$ \\
\hline & $(0.49-0.62)$ & $(0.48-0.61)$ & $(0.92-1.05)$ & $(0.87-1.00)$ & drought & 5296 & 0.59 \\
\hline & - & - & - & - & drought $\times$ canopy position & 4613 & 0.09 \\
\hline \multirow[t]{3}{*}{ DM } & 1.14 & 1.02 & 2.77 & 2.14 & canopy position & 18 & $<0.001$ \\
\hline & $(0.67-1.61)$ & $(0.55-1.50)$ & $(2.29-3.24)$ & $(1.67-2.61)$ & drought & 35 & 0.34 \\
\hline & - & - & - & - & drought $\times$ canopy position & 16 & 0.14 \\
\hline \multirow[t]{3}{*}{$\mathrm{Fn}$} & 1.63 & 1.69 & 1.22 & 1.15 & canopy position & -124 & $<0.001$ \\
\hline & $(1.46-1.79)$ & $(1.52-1.85)$ & $(1.06-1.38)$ & $(0.99-1.32)$ & drought & 219 & 0.87 \\
\hline & - & - & - & - & drought $\times$ canopy position $* *$ & -130 & 0.01 \\
\hline \multirow[t]{3}{*}{ Ln } & 9 & 8.1 & 13.3 & 10 & canopy position & -303 & $<0.001$ \\
\hline & $(7.6-10.3)$ & $(6.7-9.4)$ & $(11.9-14.6)$ & $(8.8-11.5)$ & drought & -138 & 0.17 \\
\hline & - & - & - & - & drought $\times$ canopy position ${ }^{* *}$ & -420 & $<0.001$ \\
\hline \multirow[t]{3}{*}{ LMA } & 140 & 140 & 201 & 195 & canopy position & 113 & $<0.001$ \\
\hline & $(109-171)$ & $(109-171)$ & $(170-232)$ & $(164-226)$ & drought & 127 & 0.88 \\
\hline & - & - & - & - & drought $\times$ canopy position & 117 & 0.9 \\
\hline \multirow[t]{3}{*}{ PLA } & 8.2 & 7.3 & 13.7 & 10.9 & canopy position & -59 & $<0.001$ \\
\hline & $(6.5-10.0)$ & $(5.5-9.0)$ & $(12.0-15.5)$ & $(9.2-12.7)$ & drought & -46 & 0.22 \\
\hline & - & - & - & - & drought + canopy position & -63 & 0.014 \\
\hline \multirow[t]{3}{*}{ TDn } & 0.18 & 0.19 & 0.22 & 0.24 & canopy position & -43 & 0.02 \\
\hline & $(0.14-0.23)$ & $(0.15-0.24)$ & $(0.17-0.26)$ & $(0.20-0.29)$ & drought & -38 & 0.42 \\
\hline & - & - & - & - & drought $\times$ canopy position & -41 & 0.45 \\
\hline \multirow[t]{3}{*}{ TLA } & 33 & 32 & 77 & 51 & canopy position & -12 & $<0.001$ \\
\hline & $(25-41)$ & $(23-40)$ & $(69-86)$ & $(42-59)$ & drought & 0.6 & 0.18 \\
\hline & - & - & - & - & drought $\times$ canopy position ${ }^{* *}$ & -26 & $<0.001$ \\
\hline \multirow[t]{3}{*}{ TLA/PLA } & 3.98 & 4.46 & 5.65 & 4.81 & canopy position & 33 & 0.02 \\
\hline & $(3.00-4.96)$ & $(3.48-5.44)$ & $(4.67-6.63)$ & $(3.82-5.79)$ & drought & 38 & 0.71 \\
\hline & - & - & - & - & drought $\times$ canopy position & 34 & 0.19 \\
\hline
\end{tabular}

In the drought plot light availability at the sampling position in the lower canopy varied from $16 \pm 1.7 \%$ (mean \pm SE) of the PAR in the open area around noon $(289 \pm 32$ vs. $1858 \mu \mathrm{mol} \mathrm{m}^{-2} \mathrm{~s}^{-1}$ in canopy vs. open area) to $1.6 \pm 0.07 \%$ in the late afternoon $(12.5 \pm 0.5$ vs. $782 \mu \mathrm{mol} \mathrm{m} \mathrm{m}^{-1}$ ). In the control plot light availability in the lower canopy varied from $14 \pm 0.6 \%$ (mean $\pm \mathrm{SE}$ ) of the PAR in the open area around noon ( $258 \pm 11.4$ vs. 1896 $\left.\mu \mathrm{mol} \mathrm{m} \mathrm{m}^{-2} \mathrm{~s}^{-1}\right)$ to $1.6 \pm 0.07 \%$ in the late afternoon (12.5 \pm 0.5 vs. $792 \mu \mathrm{mol} \mathrm{m} \mathrm{m}^{-2} \mathrm{~s}^{-1}-\mathrm{Ge}-$ bauer et al. 2015). Light availability at the sampling position in the upper canopy was probably similar to that in the open area since needles were collected from the tips of unshaded, south-facing branches.

Mean cumulative sap flow in the control plot was $198 \pm 21 \mathrm{~mm}$ (mean $\pm \mathrm{SE}$ ) from 17 May to 7 August 2010. This was 2.28 times higher than the sap flow in the drought plot $(87 \pm 51 \mathrm{~mm}, \mathrm{p}=0.011)$. In June 2010 , when the needle growth rate normally is at its maximum, mean cumulative sap flow was $87 \pm 5 \mathrm{~mm}$ and $34 \pm 13 \mathrm{~mm}$ in the control and drought plot, respectively (Fig. 2). Midday shoot water potential on 4 August
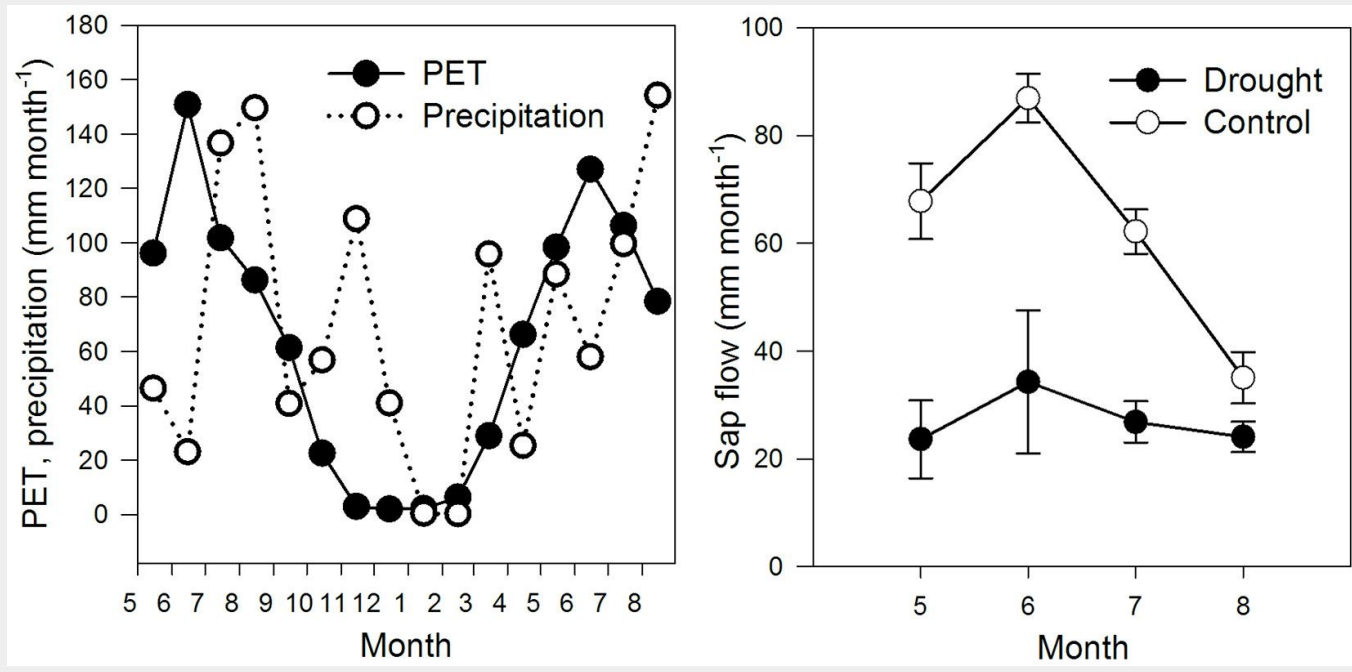

Fig. 2 - (Left): monthly sums of precipitation and Penman-Monteith based reference evapo-transpiration (PET) from May 2009 to August 2010. (Right): sap flow-based transpiration of drought stressed and control Norway spruce trees from May to August 2010 (monthly sums \pm SE, $\mathrm{n}=3)$. 
2010 averaged $-1.65 \pm 0.12 \mathrm{MPa}$ (mean \pm SEM) and $-1.80 \pm 0.0 \mathrm{MPa}$ in the control and drought-stressed trees, respectively, with no significant difference between treatments. The average transpiration of the same day was 2.03 and $1.09 \mathrm{~mm}$ in control and drought-stressed trees, respectively.

\section{Effects of canopy position on needle morphology}

For all studied needle traits we found significant differences between shade and sun needles (Tab. 2). In general, needle traits had greater values in the upper canopy than in the lower canopy (Tab. 2, Fig. 3). The only exception was $F_{n}$, which was greater in the lower canopy on both plots (Tab. 2, Fig. 3). Sun needles had $\sim 40 \%$, $\sim 70 \%$ and $\sim 130 \%$ larger LMA, $D_{2}$ and DM, respectively, than shade needles on both plots (Tab. 2). For these traits, there was no significant interaction between drought and canopy position. $\mathrm{TD}_{\mathrm{n}}$ and TLA/PLA were least influenced by canopy position, although for these traits the difference between sun and shade needles was still high $(\sim 20 \%)$. The greater $T_{D_{n}}$ of sun needles compared to shade needles was mostly caused by $D M$, which varied more than $D_{1}$, $D_{2}$ or PLA (i.e., the other traits used to calculate $\left.T D_{n}\right)$. The TLA/PLA ratio showed that TLA was 5.2-fold and 4.2-fold greater than PLA for sun and shade needles, respectively, on both plots (Tab. 2). In general, differences between shade and sun needles needle morphological traits were reduced by $12 \%$ (calculated from all studied traits) in trees subject to drought compared to control trees.

Early morphological responses to mild drought in sun and shade needles

Drought alone had no significant effect on any of the studied needle traits (Tab. 2).

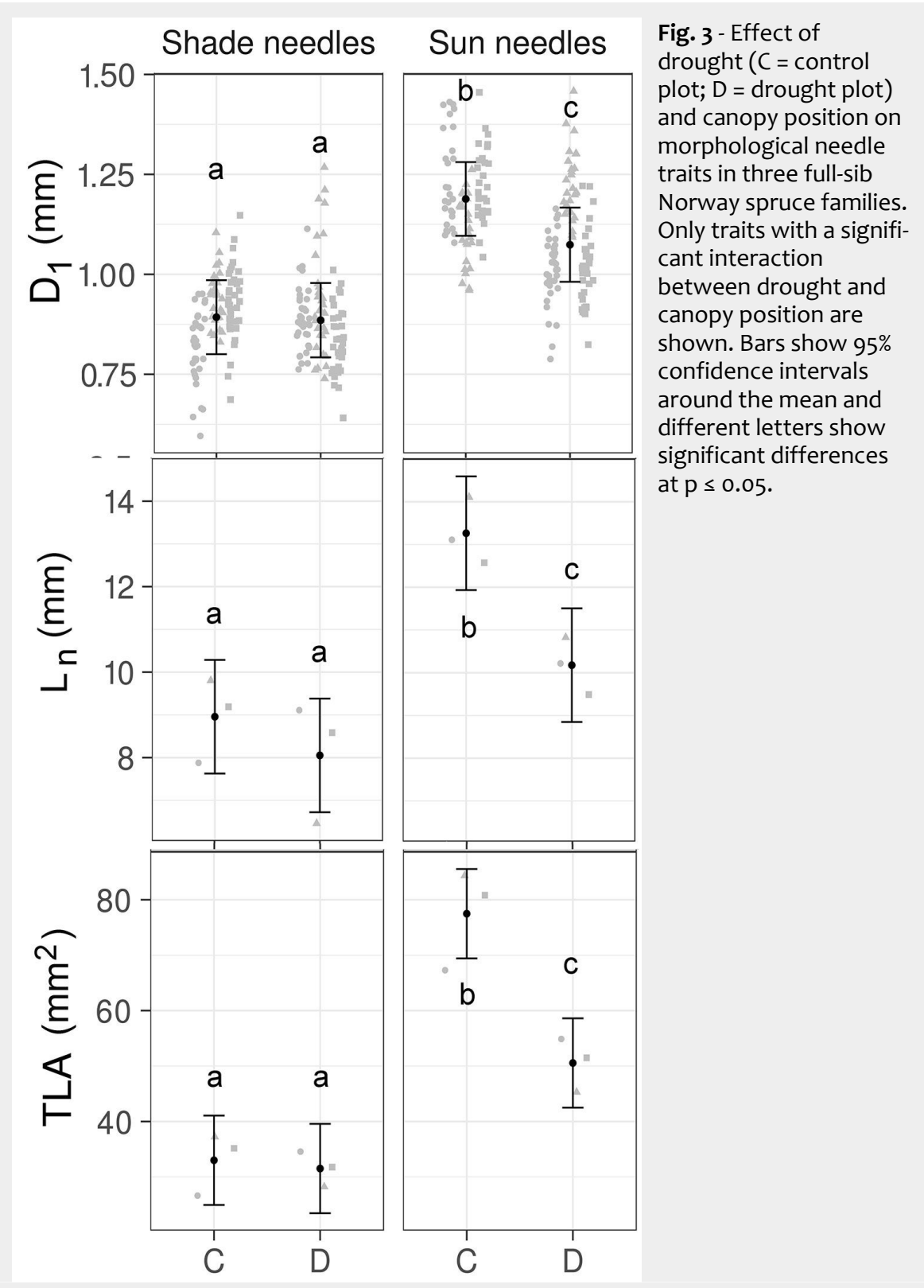

Tab. 3 - Relationship between anatomical and morphological traits of sun and shade needles from Norway spruce trees subjected to drought and control trees receiving natural rainfall. For an explanation of the different needle traits, see Tab. 1 and Methods. $(*)$ : Traits in italics are anatomical traits taken from Gebauer et al. (2015).

\begin{tabular}{|c|c|c|c|c|c|c|c|c|c|}
\hline \multicolumn{2}{|c|}{ Needle traits } & \multirow{2}{*}{$\begin{array}{l}\text { P-value for } \\
\text { needle trait } \\
<0.001\end{array}$} & \multirow{2}{*}{$\begin{array}{l}\begin{array}{l}\text { Regression } \\
\text { slope }\end{array} \\
0.5900\end{array}$} & \multirow{2}{*}{$\begin{array}{l}\begin{array}{l}\text { P-value for } \\
\text { canopy position }\end{array} \\
0.520\end{array}$} & \multicolumn{2}{|c|}{ Needle traits } & \multirow{2}{*}{$\begin{array}{l}\text { P-value for } \\
\text { needle trait } \\
<0.001\end{array}$} & \multirow{2}{*}{$\begin{array}{l}\begin{array}{l}\text { Regression } \\
\text { slope }\end{array} \\
0.0012\end{array}$} & \multirow{2}{*}{$\begin{array}{l}\text { P-value for } \\
\text { canopy position } \\
0.760\end{array}$} \\
\hline $\mathrm{D}_{1}$ & $\mathrm{D}_{2}$ & & & & $\mathrm{~L}_{\mathrm{n}}$ & $D_{1}$ & & & \\
\hline & $A_{\text {lum }}$ & 0.001 & 36.5600 & 0.060 & & $D_{2}$ & 0.220 & 0.0005 & 0.620 \\
\hline & $A_{\mathrm{n}}$ & $<0.001$ & 0.0009 & 0.790 & & $A_{\mathrm{lum}}$ & 0.150 & 0.0275 & 0.990 \\
\hline & $A_{\mathrm{x}}$ & $<0.001$ & 0.3010 & 0.330 & & $A_{\mathrm{n}}$ & 0.030 & $9.32 \cdot 10^{-7}$ & 0.940 \\
\hline & $N_{\mathrm{t}}$ & $<0.001$ & 14.2000 & 0.950 & & $A_{\mathrm{x}}$ & $<0.001$ & $6.00 \cdot 10^{-5}$ & 0.220 \\
\hline \multirow[t]{4}{*}{$D_{2}$} & $A_{\text {lum }}$ & 0.030 & 23.5700 & 0.001 & & $N_{\mathrm{t}}$ & $<0.001$ & 0.0400 & 0.320 \\
\hline & $A_{\mathrm{n}}$ & $<0.001$ & 0.0012 & $<0.001$ & \multirow[t]{4}{*}{ LMA } & $D_{1}$ & 0.844 & 0.0169 & 0.051 \\
\hline & $A_{\mathrm{x}}$ & $<0.001$ & 0.2500 & 0.010 & & $\mathrm{D}_{2}$ & 0.028 & 0.1840 & 0.559 \\
\hline & $N_{\mathrm{t}}$ & 0.001 & 12.4200 & 0.560 & & $\mathrm{TD}_{\mathrm{n}}$ & 0.001 & 609.0000 & 0.011 \\
\hline \multirow[t]{4}{*}{ DM } & $D_{1}$ & 0.029 & 0.0031 & 0.123 & & $A_{\mathrm{x}}$ & 0.655 & 0.0096 & 0.069 \\
\hline & $\mathrm{D}_{2}$ & 0.007 & 0.0042 & 0.473 & \multirow[t]{3}{*}{$T D_{n}$} & $D_{1}$ & 0.206 & -0.0002 & 0.036 \\
\hline & $\mathrm{TD}_{\mathrm{n}}$ & 0.623 & 2.1000 & 0.002 & & $D_{2}$ & 0.142 & 0.0002 & 0.512 \\
\hline & $A_{\mathrm{x}}$ & 0.108 & 0.0007 & 0.089 & & $A_{\mathrm{x}}$ & 0.983 & $6.7 \cdot 10^{-7}$ & 0.247 \\
\hline
\end{tabular}


For many traits, this was partly due to the fact that shade and sun needles differ in their early morphological responses to drought. For five of the 10 studied needle traits $\left(D_{1}, F_{n}, L_{n}, P L A\right.$ and TLA) the drought $x$ canopy position interaction was significant (Tab. 2, Fig. 3), and in-depth analysis of this interaction revealed that only sun needles were affected by drought (Tab. 2). The greatest influence of drought on sun needles was observed for $L_{n}$, PLA and TLA, which were reduced by 27,10 and $32 \%$, respectively, relative to control trees (Tab. 2). The drought $\times$ canopy position interaction was non-significant for $D_{2}, D M, L M A, T D_{n}$ and the TLA/PLA ratio (Tab. 2). $D_{1}$ and $D_{2}$ showed different sensitivity to drought, as only the thickness of sun needles was reduced by drought ( $10 \%$ reduction). The reduced thickness of sun needles in response to drought corresponded with the observed decrease in sun needle flatness in the drought plot (Tab. 2).

\section{Relationships among morphological and anatomical needle traits}

The morphological traits measured at the individual needle level $\left(D_{1}, D_{2}, L_{n}\right)$ showed a significant relationship with most of the selected anatomical and morphological needle traits (Tab. 3). For needle traits measured at the canopy position level (DM, LMA, $T D_{n}$ ), half of the tested relationships were significant for DM and LMA, whereas only one significant relationship was found for $\operatorname{TD}_{n}(T a b .3)$. All the significant relationships found among needle traits were positive (Tab. 3). Canopy position tended to have little effect on the relationship between traits, as only six of 26 tested relationships were significant (Tab. 3 ).

\section{Discussion}

\section{Effects of canopy position on needle morphology}

Previous studies have shown that needle development within tree canopies is mostly influenced by long-term light availability, which leads to anatomical (Gebauer et al. 2015) and morphological changes (Ellsworth \& Reich 1993, Niinemets et al. 2007). This was also supported by our study, as we found that shade needles in the lower canopy had significantly smaller values for morphological traits compared to sun needles in the upper canopy. Thus our first hypothesis was supported.

The lower LMA of shade needles compared to sun needles reflects the higher efficiency with which these needles capture light relative to the biomass invested. The pattern of LMA variation found within tree canopies also enhances the foliage's capacity for photosynthesis under conditions of high light intensities and their light harvesting efficiency under low light intensities (Niinemets et al. 1998). The range of LMA values found in our study $\left(115-223 \mathrm{~g} \mathrm{~m}^{-2}\right)$ was broad but falls within the range found by others for Norway spruce trees (Hager
\& Sterba 1985, Konôpka et al. 2016). The variation in LMA that we observed within Norway spruce crowns were mostly attributed to changes in needle width $\left(D_{2}\right)$ and needle tissue density $\left(T_{n}\right)$.

Sun needles were longer and had larger projected needle area than shade needles, reflecting their increased capacity for light capture. Needle length was also positively correlated with needle xylem area and tracheid number $\left(A_{x}\right.$ and $\left.N_{t}\right)$, consistent with a higher water transport capacity of the longer sun needles. Although the xylem in Norway spruce needles consists of thickwalled tracheids, we found no strong relationship between $T D_{n}$ and $A_{x}$. This is probably because the xylem makes up a very small proportion of total needle cross-sectional area in Norway spruce (0.3\% according to Gebauer et al. 2015).

In our study, $\mathrm{TD}_{\mathrm{n}}$ was higher in sun needles in the upper canopy than in shade needles in the lower canopy. A similar trend was also found for Tsuga heterophylla (Raf.) Sarg. (Richardson et al. 2001) and Pinus radiata D. Don (Niinemets et al. 2007). Nevertheless, an extensive review of the literature has shown that a wide range of relationships exists between $\mathrm{TD}_{\mathrm{n}}$ and light intensity (equivalent to canopy position) among conifers (Niinemets 1997). This review concluded that $T D_{n}$ is determined by other environmental factors that inherently accompany light gradients. Moreover, a positive relationship exists between $\mathrm{TD}_{\mathrm{n}}$ and needle carbon content per needle dry mass, and higher needle carbon content may be attributed to increased thickening and lignification of needle cell walls (Niinemets 1997). This assumption is supported by our finding that $T D_{n}$ was more influenced by needle dry mass (DM) than by $D_{1}$ or PLA (i.e., the other traits used to calculate $T D_{n}$ ). The higher $T D_{n}$ of sun needles means that sun needles require a higher energy investment than shade needles, but the net effect on the tree's energy budget is probably outweighed by their higher photosynthetic activity (Niinemets et al. 1998).

In Norway spruce needle thickness $\left(D_{1}\right)$ tends to become larger and less variable than needle width $\left(D_{2}\right)$ going from the lower to the upper canopy (Niinemets \& Kull 1995, Niinemets 1997) and our data replicated this pattern. However, the relationship between $D_{1}$ and $D_{2}$ was still highly significant and positive. Both $D_{1}$ and $D_{2}$ were also positively correlated with all the studied anatomical needle traits $\left(A_{\text {lum }}, A_{n}\right.$, $A_{x}$ and $N_{t}$ ). In an ecological context, it may be advantageous for the trees to increase the thickness of sun needles, as it increases the needle mesophyll area per surface area which in turn increases the diffusive conductance of the mesophyll to $\mathrm{CO}_{2}$ (Niinemets \& Kull 1995, Lhotáková et al. 2012). Moreover, thick needles are expected to have greater light absorbance than thin needles due to increasing path length (Oquist et al. 1982). The higher sensitivity of $D_{2}$ to canopy position compared to $D_{1}$ results in variation in needle flatness $\left(F_{n}\right)$ within Norway spruce crowns. The different sensitivity of $D_{1}$ and $D_{2}$ to canopy position is also influencing the TLA/PLA ratio, as smaller ratios are characteristic of more flattened needles.

\section{Early morphological responses to mild drought in shade needles}

In our study, the morphology of shade needles developing under mild drought conditions was very similar to that of shade needles in the control trees. Thus, our second hypothesis was not supported for shade needles. Part of the reason for this may be that shade needles experienced less drought stress than sun needles. In Norway spruce, shade needles have significantly higher water potential than sun needles (Schulze et al. 1985, Sellin \& Kupper 2004). Also, shade needles have low overall transpiration rates (Schulze et al. 1985, Sellin \& Kupper 2004). Transpiration rates would be low for shade needles in both drought-stressed trees and control trees because the lower light intensities and wind speeds typically found at the bottom of the canopy reduce water vaporization. Another reason for the weak drought response of shade needles could be that these needles are already physiologically constrained and operate close to their survival threshold (Sellin \& Kupper 2004). Because of their small size and reduced photosynthesis (Bertamini et al. 2006) and hydraulic conductivity (Gebauer et al. 2015), further structure reductions in shade needles might lead to needle mortality, needle shedding and eventually death of branches.

We should emphasize that the trees in our drought plot still received some water from deeper soil layers. This allowed them to maintain $44 \%$ of the transpiration level of the control trees. The moderate soil water potential measured in deeper soil layers $(-0.42 \mathrm{MPa})$ indicated that our experimental trees were experiencing mild drought stress. The minimum water potential of -1.8 MPa indicated that trees subject to drought stress were far from the water potential inducing $50 \%$ loss of xylem hydraulic conductivity. This threshold has been found to be -2.5 MPa for 24-year-old Norway spruce in Sweden (Rosner et al. 2008) and $-4 \mathrm{MPa}$ for young Norway spruce in southern Poland (Chmura et al. 2016). The minimum water potential in our study was also higher than the typical turgor loss point for Norway spruce of about $-3 \mathrm{MPa}$ (Gross \& Koch 1991). The relatively mild drought stress experienced by our experimental trees clearly does not kill the trees in a short time, but even mild drought stress with a minimum water potential of -1.8 MPa affected tree anatomy and physiology (i.e., transpiration, stomatal conductance, and photosynthesis). Such effects may persist for several weeks and even after re-watering (Chmura et al. 2016). 
Early morphological responses to mild drought in sun needles

Smaller cell dimensions are a typical out come when drought stress occurs during tree development, due to reduced turgor in the cell elongation phase (Chaves et al. 2003). Our observations fit with this pattern, as drought reduced five of the ten studied sun needle traits by 6 to 34\%. Thus, our second hypothesis was supported for sun needles. This also means that drought had a higher impact on sun needles than on shade needles, thus supporting our third hypothesis. The extensive morphological plasticity we observed in sun needles 15 months after the onset of drought also confirms that needles are among the tree parts that are most sensitive to environmental changes (Eldhuset et al. 2013). Mild drought stress is known to cause much less pronounced structural modification of needles than severe drought (Eldhuset et al. 2013). Consequently, the increase in LMA and $T D_{n}$ observed in several studies of severe drought stress (Niinemets 2001, Hallik et al. 2009) was not observed in our study. However, we cannot rule out that mild but prolonged drought stress would result in stronger morphological needle plasticity. Although we observed extensive plasticity of sun needle morphology to drought in this study, we found even stronger reductions in anatomical needle traits at the cellular level in a previous study (10 to $45 \%$ reductions - Gebauer et al. 2015).

\section{Conclusion}

Canopy position influenced all the morphological needle traits we studied. Our results also showed that early morphological responses to drought differ between sun and shade needles: sun needles underwent pronounced morphological changes, while no such plastic responses were observed in shade needles. The interactive effect of drought and canopy position resulted in smaller morphological differences between needle types in trees subject to drought stress vs. control trees, as sun adapted needles in the upper crown were more affected by drought than shade adapted needles at the bottom of the crown.

Our results demonstrate that canopy position and water availability may modify the morphology of Norway spruce needles in diverse ways. We propose that unaccounted differences in water availability could explain some of the inter-specific variability reported for conifers in the relationship between needle morphology and light intensity. However, the generality of our results needs to be confirmed by further replication of our morphological studies across Norway spruce genotypes and different soil and environmental conditions.

\section{Acknowledgments}

This work was funded by the project "In- dicators of Tree Vitality" (Reg. No. CZ.1.07/ 2.3.00/20.0265) co-financed by the European Social Fund and the Czech Republic, by Iceland, Liechtenstein and Norway through the EEA Financial Mechanism (grant no. A/CZ0046/2/0009), by the Ministry of Education, Youth and Sports of the Czech Republic (Grant INTER-TRANSFER LTT17033), and by Mendel University in Brno (grant no. IGA 73/2013). We would also like to acknowledge the contribution of the COST Action FP1106, STReESS. We are grateful to Jaromíra Dreslerová, Alžbeta Malotínová and Darina Smerekovská for laboratory work. We would like to thank several anonymous reviewers for their constructive comments, which improved the manuscript.

\section{Conflict of interest}

The authors declare that they have no conflict of interest.

\section{References}

Aranda I, Castro L, Pardos M, Gil L, Pardos JA (2005). Effects of the interaction between drought and shade on water relations, gas exchange and morphological traits in cork oak (Quercus suber L.) seedlings. Forest Ecology and Management 210: 117-129. - doi: 10.1016/j.for ec0.2005.02.012

Bates D, Maechler M, Bolker B, Walker S (2014). _Ime4: Linear mixed-effects models using Eigen and S4_. R package version 1.1-7. [online] URL: http://CRAN.R-project.org/package=Ime4

Bertamini M, Muthuchelian K, Nedunchezhian N (2006). Shade effect alters leaf pigments and photosynthetic responses in Norway spruce (Picea abies L.) grown under field conditions. Photosynthetica 44: 227-234. - doi: 10.1007/s11099-006-0011-z

Børja I, Douglas LG, Svetlík J, Nagy NE, Gebauer $\mathrm{R}$, Urban J, Volarík D, Lange H, Krokene P, Cermák P, Eldhuset TD (2017). Springer International Publishing, New York, USA, pp. 123-142. doi: 10.1007/978-3-319-63336-7_8

Chaves MM, Maroco JP, Pereira JS (2003). Understanding plant responses to drought - from genes to the whole plant. Functional Plant Biology 30: 239-264. - doi: 10.1071/FP02076

Chmura DJ, Guzicka M, McCulloh KA, Zytkowiak $R$ (2016). Limited variation found among Norway spruce half-sib families in physiological response to drought and resistance to embolism. Tree Physiology 36: 252-266. - doi: 10.1093/tree phys/tpv141

Cermák J, Deml M, Penka M (1973). A new method of sap flow rate determination in trees. Biologia Plantarum 15: 171-178. - doi: 10.10 07/BF02922390

Eldhuset T, Nagy N, Volarík D, Børja I, Gebauer R, Yakovlev I, Krokene P (2013). Drought affects tracheid structure, dehydrin expression, and above- and belowground growth in 5-year-old Norway spruce. Plant and Soil 366: 305-320. doi: 10.1007/s11104-012-1432-z

Ellsworth DS, Reich PB (1993). Canopy structure and vertical patterns of photosynthesis and related leaf traits in a deciduous forest. Oecologia 96: 169-178. - doi: 10.1007/BFo0317729

Gebauer R, Volarík D, Urban J, Børja I, Nagy NE,
Eldhuset TD, Krokene P (2011). Effect of thinning on the anatomical adaptation of Norway spruce needles. Tree Physiology 31: 1103-1113. doi: 10.1093/treephys/tpro81

Gebauer R, Volarík D, Urban J, Børja I, Nagy NE, Eldhuset TD, Krokene P (2015). Effects of prolonged drought on the anatomy of sun and shade needles in young Norway spruce trees. Ecology and Evolution 5: 4989-4998. - doi: 10.1002/ece3.1766

Gross K, Koch W (1991). Water relations of Picea abies. I. Comparison of water relations parameters of spruce shoots examined at the end of the vegetation period and in winter. Physiologia Plantarum 83: 290-295. - doi: 10.1111/j.13993054.1991.tbo2155.x

Hager H, Sterba H (1985). Specific leaf area and needle weight of Norway spruce (Picea abies) in stands of different densities. Canadian Journal of Forest Research 15: 389-392. - doi: 10.1139 1x85-062

Hallik L, Niinemets U, Wright IJ (2009). Are species shade and drought tolerance reflected in leaf-level structural and functional differentiation in Northern Hemisphere temperate woody flora? New Phytologist 184: 257-274. - doi: 10.111 1/j.1469-8137.2009.02918.x

Hansen VT, Grimenes AA (2003). Meteorologiske data for Ås 2002 [Meteorological data for Ås 2002]. Department of Engineering, Norwegian University of Life Science, Ås, Norway. [in Norwegian]

Hentschel R, Rosner S, Kayler ZE, Andreassen K, Børja I, Solberg S, Tveito OE, Priesack EP, Gessler A (2014). Norway spruce physiological and anatomical predisposition to dieback. Forest Ecology and Management 322: 27-36. - doi: 10.1016/j.foreco.2014.03.007

Holmgren M (2000). Combined effects of shade and drought on tulip poplar seedlings: trade-off in tolerance or facilitation? Oikos 90: 67-78. doi: 10.1034/j.1600-0706.2000.900107.x

Kivimäenpää M, Sutine S, Karlsson PE, Sellden C (2003). Cell structural changes in the needles of Norway spruce exposed to long-term ozone and drought. Annals of Botany 92: 779-793. doi: $10.1093 / \mathrm{aob} / \mathrm{mcg} 202$

Konôpka B, Lukac M (2013). Moderate drought alters biomass and depth distribution of fine roots in Norway spruce. Forest Pathology 43: 115-123. - doi: 10.1111/efp.12005

Konôpka B, Pajtík J, Marušák R, Bošela M, Lukac $M$ (2016). Specific leaf area and leaf area index in developing stands of Fagus sylvatica L. and Picea abies Karst. Forest Ecology and Management 364: 52-59. - doi: 10.1016/j.foreco.2015.12. 005

Kubínová Z, Janáček J, Lhotáková Z, Sprtová M, Kubínová L, Albrechtová J (2018). Norway spruce needle size and cross section shape variability induced by irradiance on a macro- and microscale and $\mathrm{CO}_{2}$ concentration. Trees-Structure and Function 32: 231-244. - doi: 10.1007/ s00468-017-1626-3

Kučera J, Bednarova E, Kamlerova K (2002). Vertical profile of needle biomass and penetration of radiation through the spruce stand. Ekologia 21: 107-121.

Kurjak D, Strelcová K, Ditmarová L, Priwitzer T, Kmet J, Homolák M (2012). Physiological response of irrigated and non-irrigated Norway 
spruce trees as a consequence of drought in field conditions. European Journal of Forest Research 131: 1737-1746. - doi: 10.1007/s10342-0120611-z

Kuznetsova A, Brockhoff PB, Christensen RHB (2015). ImerTest: tests in linear mixed effects models. R package version 2.0-25. [online] URL: http://CRAN.R-project.org/package=ImerTest Lhotáková Z, Albrechtová J, Malenovsky Z, Rock BN, Polák T, Cudlín P (2007). Does the azimuth orientation of Norway spruce (Picea abies [L.] Karst.) branches within sunlit crown part influence the heterogeneity of biochemical, structural and spectral characteristics of needles? Environmental and Experimental Botany 59: 283-292. - doi: 10.1016/j.envexpbot.2006.02.003 Lhotáková Z, Urban O, Dubánková M, Cvikrová M, Tomášková I, Kubínová L, Zvára K, Marek MV, Albrechtová J (2012). The impact of longterm $\mathrm{CO}_{2}$ enrichment on sun and shade needles of Norway spruce (Picea abies): photosynthetic performance, needle anatomy and phenolics accumulation. Plant Science 188: 60-70. - doi: 10.1016/j.plantsci.2012.02.013

Niinemets U, Kull O (1995). Effects of light availability and tree size on the architecture of assimilative surface in the canopy of Picea abies: variation in needle morphology. Tree Physiology 15: 307-315. - doi: 10.1093/treephys/15.5.307 Niinemets U (1997). Distribution patterns of foliar carbon and nitrogen as affected by tree dimensions and relative light conditions in the canopy of Picea abies. Trees-Structure and Function 11: 144-154. - doi: 10.1007/PLo0009663 Niinemets U, Kull O, Tenhunen JD (1998). An analysis of light effects on foliar morphology, physiology, and light interception in temperate deciduous woody species of contrasting shade tolerance. Tree Physiology 18: 681-696. - doi: 10.1093/treephys/18.10.681

Niinemets U (2001). Global-scale climatic controls of leaf dry mass per area, density, and thickness in trees and shrubs. Ecology 82: 453469. - doi: 10.1890/0012-9658(2001)082[0453:G SCCOL]2.0.CO;2

Niinemets U, Lukjanova A, Turnbull MH, Sparrow $A D$ (2007). Plasticity in mesophyll volume fraction modulates light-acclimation in needle pho- tosynthesis in two pines. Tree Physiology 27: 1137-1151. - doi: 10.1093/treephys/27.8.1137

Oquist G, Brunes L, Hällgren J-E (1982). Photosynthetic efficiency of Betula pendula acclimated to different quantum flux densities. Plant Cell and Environment 5: 9-15. - doi: 10.1111/ 1365-3040.ep11587416

R Core Team (2015). R: a language and environment for statistical computing. R Foundation for Statistical Computing, Vienna, Austria. [online] URL: http://www.r-project.org/

Richardson AD, Ashton PMS, Berlyn GP, McGroddy ME, Cameron IR (2001). Within-crown foliar plasticity of western hemlock, Tsuga heterophylla, in relation to stand age. Annals of Botany 88: 1007-1015. - doi: 10.1006/anbo.2001. 1538

Rosner S, Klein A, Müller U, Karlsson B (2008). Tradeoffs between hydraulic and mechanical stress responses of mature Norway spruce trunk wood. Tree Physiology 28: 1179-1188. - doi: 10.1093/treephys/28.8.1179

Schulze E-D, Cermák J, Matyssek M, Penka M, Zimmermann R, Vasícek F, Gries W, Kučera J (1985). Canopy transpiration and water fluxes in the xylem of the trunk of Larix and Picea trees a comparison of xylem flow, porometer and cuvette measurements. Oecologia 66: 475483. - doi: 10.1007/BF00379337

Sellin A (2000). Estimating needle area from geometric measurements: application of different calculation methods to Norway spruce. Trees - Structure and Function 14: 215-222. - doi: 10.1007/PLooo09765

Sellin A (2001). Morphological and stomatal responses of Norway spruce foliage to irradiance within a canopy depending on shoot age. Environmental and Experimental Botany 45: 115-131. - doi: 10.1016/S0098-8472(00)00086-1

Sellin A, Kupper P (2004). Within-crown variation in leaf conductance of Norway spruce: effects of irradiance, vapour pressure deficit, leaf water status and plant hydraulic constraints. Annals of Forest Science 61: 419-429. - doi: 10.1051/forest:2004035

Sohn JA, Kohler M, Gessler A, Bauhus J (2012). Interactions of thinning and stem height on the drought response of radial stem growth and isotopic composition of Norway spruce (Picea abies). Tree Physiology 32: 1199-1213. - doi: 10.1093/treephys/tps077

Strelcová K, Kurjak D, Leštianska A, Kovalčíková D, Ditmarová L, Skvarenina J, Ahmed YAR (2013). Differences in transpiration of Norway spruce drought stressed trees and trees well supplied with water. Biologia 68: 1118-1122. - doi: 10.2478/s11756-013-0257-4

Spunda V, Cajánek M, Kalina J, Lachetová I, Sprtová M, Marek MV (1998). Mechanistic differences in utilization of absorbed excitation energy within photosynthetic apparatus of Norway spruce induced by the vertical distribution of photosynthetically active radiation through the tree crown. Plant Science 133: 155165. - doi: 10.1016/S0168-9452(98)00031-4

Turtola S, Manninen A, Rikala R, Kainulainen P (2003). Drought stress alters the concentration of wood terpenoids in Scots pine and Norway spruce seedlings. Journal of Chemical Ecology 29: 1981-1995. - doi: 10.1023/A:1025674116183

Van Pol M, Wright J (2009). A simple method for distinguishing within- versus between-subject effect using mixed models. Animal behaviour 77: 753-758. - doi: 10.1016/j.anbehav.2008.11.006 Wallin G, Karlsson PE, Sellden G, Ottosson S, Medin EL, Pleijel H, Skarby L (2002). Impact of four years exposure to different levels of ozone, phosphorus and drought on chlorophyll, mineral nutrients, and stem volume of Norway spruce, Picea abies. Physiologia Plantarum 114: 192-206. - doi: 10.1034/j.1399-3054. 2002.1140205.x

Woodruff DR, Bond BJ, Meinzer FC (2004). Does turgor limit growth in tall trees? Plant Cell and Environment 27: 229-236. - doi: 10.1111/j.13653040.2003.01141.x

Zellnig G, Zechmann B, Perktold A (2004). Morphological and quantitative data of plastids and mitochondria within drought-stressed spinach leaves. Protoplasma 223: 221-227. - doi: 10.1007/ s00709-003-0034-2

Zuur AF, leno EN, Walker NJ, Saveliev AA, Smith GM (2009). Mixed effects models and extensions in ecology with R. Springer, New York, USA, pp. 574 . 